\title{
A Behavioural Study of Free Ranging Ceylon Spotted Deer (Axis axis ceylonensis) in Trincomalee, Sri Lanka
}

\author{
Kalpphana Gowrithasan ${ }^{1}$, Ahamed Muhaideen Riyas Ahamed ${ }^{2 *}$, Meena Dharmaretnam ${ }^{3}$ \\ 'Department of Zoology, Eastern University, Sri Lanka, Chenkalady, Sri Lanka \\ ${ }^{2}$ Department of Biological Sciences, South Eastern University of Sri Lanka, Sammanthurai, Sri Lanka \\ ${ }^{3}$ Science Navigators, Batticaloa, Sri Lanka
}

\section{ARTICLE INFO}

Article history:

Received January 12, 2021

Received in revised form September 23, 2021

Accepted September 27, 2021

\section{KEYWORDS}

Axis axis ceylonensis,

Trincomalee,

behaviour,

food preference,

bimodal activity

\begin{abstract}
Axis axis ceylonensis (Ceylon spotted deer) is a sub species endemic to Sri Lanka. Ecological observations in wild populations of this subspecies have been reported but there is no published research on its behaviour. We report here a behavioural study on a free ranging population of $A$. $a$. ceylonensis inhabiting a temple surroundings in Trincomalee, Sri Lanka. Behaviour was quantified by focal sampling on sex age groups in three time zones: $6: 30$ to $7: 30,12: 30-13: 30$, and 17:00 to 18:00 hours. The deer were more active in the hour after dawn and an hour before dusk. The main activities were feeding and play, the latter common in juveniles. There was a preference to graze on grasses and browse on Ficus sp. leaves. Resting was highest in the afternoon across all groups. This bimodal activity pattern is similar to that of both wild Ceylon and Indian $A$. axis subspecies despite the absence of predators in the study area. The bimodal activity may be related to thermoregulatory functions while grazing in open grass areas.
\end{abstract}

\section{Introduction}

There are four species of deer belonging to family Cervidae recorded in Sri Lanka: Rusa unicolor (Sambur), Axis porcinus (hog deer), Muntiacus muntjack (barking deer) and A. axis (spotted deer) (Weerakoon 2012). There are two subspecies of $A$. axis: Axis axis ceylonensis Fischer, 1829 (Ellerman and Morrison-Scott 1951; Phillips 1980) endemic to Sri Lanka and $A$. a. axis distributed in the Indian subcontinent and commonly called chital in Hindi (Prater 1971). A. a. ceylonensis, the Ceylon spotted deer (tithmuwa in Sinhalese and Pulli maan in Tamil) has a status of least concern and is more common of the four species of Cervidae.

A. a. ceylonensis commonly inhabits wooded areas in the low country dry zones (Phillips 1980). A. axis has been introduced to other countries such as Australia, the Andaman Islands, Hawaii, Texas (Lever 1985). They are also kept in captivity in zoos (Khadka 2012) and in a few countries farmed for venison and antlers (English 1992). Even though the Ceylon spotted deer has a status of least concern (Weerakoon 2012), Santiapillai and Wijemohan (2003) warn

\footnotetext{
* Corresponding Author

E-mail Address: riyasahame@seu.ac.lk
}

that the population may have decreased drastically as they are poached for venison. Ecological and behavioural understanding is an important aspect in the conservation of the subspecies endemic to Sri Lanka.

Behavioural studies are an important aspect of conservation (Sutherland 1998). Such studies on the Indian spotted deer have been reported (Sharatchandra and Gadgil 1980; Moe and Wegge 1994; Tak and Lamba 1994; Khanpara and Kauresh 2011; Rajawat and Chandra 2020). Observations on range, feeding habit and group size of the Ceylon spotted deer in the Wilpattu National Park (Eisenberg and Lockhart 1972) Yala National Park (de Silva and de Silva 2001) and Ruhunu National Park (Balasubramaniam et al. 1980) have been reported. These focussed on the ecological aspects such as group size, range etc. There are no studies on the behaviour of the Ceylon spotted deer, de Silva and de Silva (2001) arrived at the bimodal pattern of activity by looking at the numbers of deer on the grass and not quantified behaviour per se.

A feeding peak around dawn and dusk and resting at noon have been noted in $A$. axis (de Silva and de Silva 2001; Dave 2008; Rajawat and Chandra 2020) and Table 1 . The cause of this bimodal pattern has been widely discussed and attributed to avoiding 
predators (Leuthold 1977). As our study area is devoid of predators and as the deer are habituated to humans, the influence of predators on the bimodal activity was also explored.

A free ranging population of about 520 Ceylon spotted deer is found in the vicinity of a temple in Trincomalee, Sri Lanka (Daily News 2018). This population provided an opportunity to study behaviour in their natural environment.

The aim of the study was to carry out age, sex comparison of the different behaviours observed during three time zones: morning, noon and evening. Food preferences were also recorded.

\section{Materials and Methods}

\subsection{Study Area}

Free ranging $A$. a. ceylonensis are found mainly inhabiting a peninsula in the town of Trincomalee, east coast of Sri Lanka $\left(8.58^{\circ} \mathrm{N} 81.25^{\circ} \mathrm{E}\right)$. This area lies in the dry zone: with a temperature range of $24-35^{\circ} \mathrm{C}$ and an annual rainfall of $1,000-1,500 \mathrm{~mm}$, mostly received during the northeast monsoon (October to February). Sunrise is between $5.45-6.25$ and sunset is between 17.57-18.28 hours. The Koneswaram temple and the fort are situated in a small peninsula projecting into the Indian Ocean (Figure 1). This is not a residential area but there are visitors to the temple. The area has no natural predators. Typical dry scrub vegetation and grass provide habitat for the deer population. The deer are considered sacred by locals as it is believed that they belonged to the temple initially.

\subsection{Subjects}

Individuals among the population were selected so that there were 21 of each age and sex group. Adult males were identified by the presence of antlers and

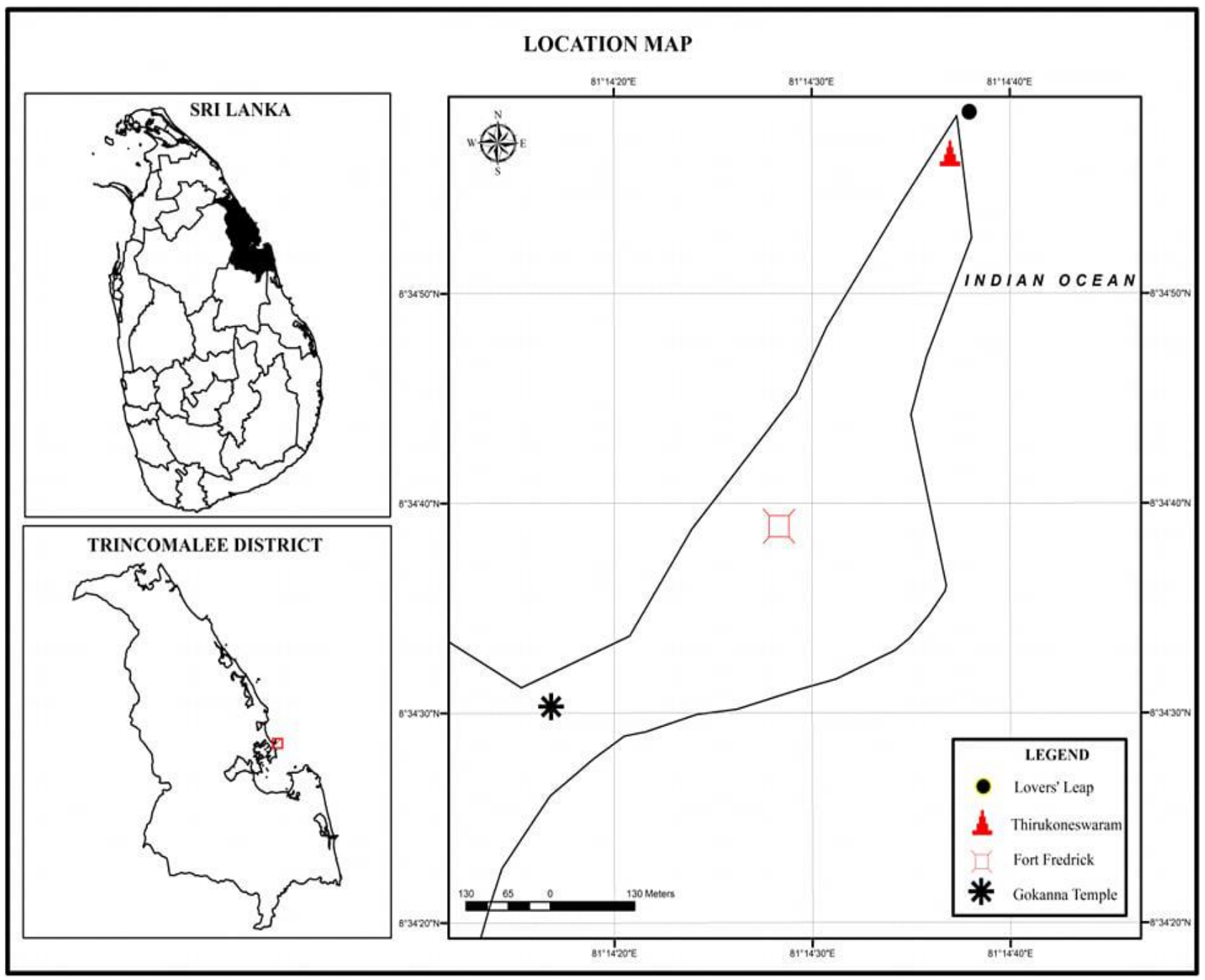

Figure 1. Study area in Trincomalee, Sri Lanka. The free ranging Ceylon spotted deer inhabits the peninsula, which is not a residential area and has a temple and fort 
larger size, females by larger size and absence of antlers and the juveniles by the smaller size and glossy coats (Eisenberg and Lockhart 1972; Sharatchandra and Gadgil 1980). As a preliminary study was done earlier, the deer was habituated to the researcher. Individuals were recognised by their features-antler shape and size and anatomical features. Observations on individuals were not repeated as we selected individuals occupying different areas of the peninsula (Figure 2).

\subsection{Method}

Behavioural observations were carried out during daytime in three samples periods as focal sampling (Altman 1974): 06:30 to 07:30, 12:30-13:30 and 17:00 to 18:00 hours. We chose to observe a window of one hour in each time zone during the day as it will be easier to compare behaviour statistically (Vas and Andersen 2015) and enabled us to get more detailed behavioural data as one animal was continuously observed for one hour. The selection of timing was based on a preliminary study of the subjects. A total of 11,340 minutes of observations were made with 21 animals in each age sex group. The subjects were selected from different herds in different locations to make sure that each individual was observed only once so that the data was independent. The following behavioural patterns were recorded in the study: feeding, resting and play, as they were more common than other behaviours like grooming, antipredator and stress. Precautions were taken so that the deer were not disturbed by the observer.

Food preference: The types of food were noted as frequency of bites and the species of plant/food utilised (Dave 2008).

Feeding behaviour was defined as: mouth activity close to the ground, browsing on leaves, feeding on bread and other food provided by humans, drinking water and standing whilst need full stop after

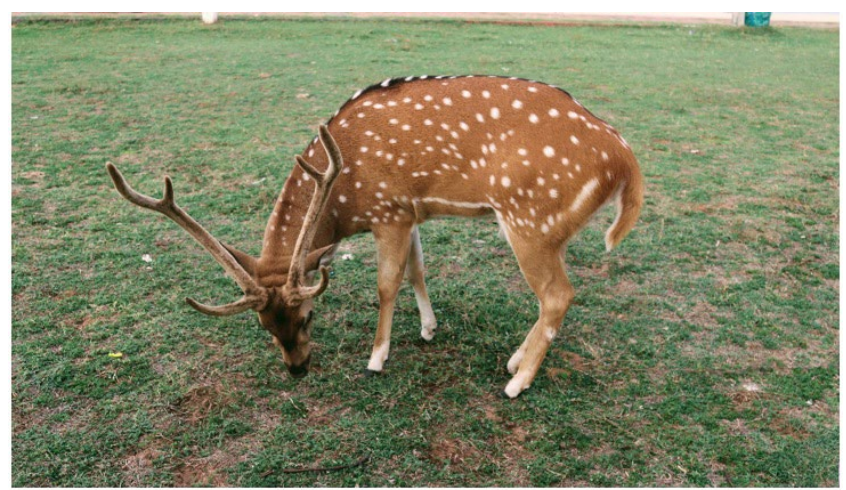

Figure 2. Axis axis ceylonensis (Ceylon spotted deer) inhabiting the peninsula area in Trincomalee, Sri Lanka ruminating. Resting behaviour was defined as lying on the ground sleeping (bedding), ruminating or standing still. Play behaviour was defined as running, leaping, turning etc., seemingly non-functional and not caused by stress (Graf and Nichols 1966; Sharatchandra and Gadgil 1980; Burghardt 2005). Sparring shown by juveniles were also considered play behaviour (Graf and Nichols 1966).

Data analysis: The observations were classified into different behavioural patterns. For each behaviour, total duration per animal, mean duration, standard deviation (given in text) and standard error (in graphs) were calculated. Two-way ANOVA were done for each behaviour (SAS, System for Windows 9.0). Significant overall ANOVA was followed by DMRT. Significant level was 0.05 .

\section{Results}

\subsection{Feeding Behaviour}

There was a significant difference between the time zones for feeding $(\mathrm{F}=121.4, \mathrm{p}<0.0001)$. Feeding activity was mostly observed in the morning and evening. A DMRT indicated that the mean in the morning was significantly higher followed by evening and lowest was at noon (Figure 3). Feeding was highest in the morning for both adults and young (Figure 3 ). In males, the mean time spent in feeding in the morning was highest (29.29 \pm 6.39$)$ minutes, followed by evening $(21.19 \pm 6.44)$ and noon was $17.38 \pm 4.45$ minutes. In females time spent in feeding was highest in the morning $(31.67 \pm 6.39)$, followed by evening $(22.86 \pm 6.44)$, minimum time was spent at noon $(18.81 \pm 4.45)$. In the young the mean time spent in feeding in the morning was $24.29( \pm 6.77)$ minutes, followed by evening $(13.81 \pm 3.84)$ and noon was $10.48( \pm 3.50)$ minutes. The adults fed for a longer time than juveniles in all three time zones $(\mathrm{F}=52.17$, $\mathrm{p}<0.0001)$. However, the feeding pattern in the three time zones were similar in males, females and juveniles as the time and age/sex interaction was not significantly different $(\mathrm{F}=0.39, \mathrm{p}=0.8153)$. Females spent more time feeding (52.8\%) than males (48.8\%), but this is not significantly different $(\mathrm{F}=1.98752, \mathrm{p}=0.161)$.

The deer utilized more than five plant species, bread and rice (Figure 4). The feed included grass and foliage of Ficus, Azadirachta, Tridax and Albizia spp. The deer also fed readily on food provided by humans: rice and bread. The preferred food was grass $(4.95 \pm 2.40)$ and Ficus sp. foliage (3.77 \pm 2.15$)$ followed by bread $(1.77 \pm 1.00)$, rice (2.14 \pm 1.71$)$, Tridax sp. (1.45 \pm 1.34$)$ and Albizia sp. $(1.05 \pm 1.26)(\mathrm{F}=16.377, \mathrm{p}<0.0001)$. Occasionally, the deer also fed on the foliage of Mangifera, Psidium, Acacia, and Terminalia spp. These were rare and not taken into consideration for analysis. 


\subsection{Play Behaviour}

Juveniles spent more time (14.81\%) than adults in play behaviour $(\mathrm{F}=18.5, \mathrm{p}<0.0001)$, the highest time spent in play was in the morning $(10.95 \pm 6.45)$ and evening $(10.71 \pm 7.95)$. Least time was spent in play during noon $(5.00 \pm 4.18)$. In males play behaviour (Figure 5) was higher in the morning (7.86 \pm 5.14$)$ and evening $(8.81 \pm 5.90)$ the least time spent in playing was at noon (3.10 \pm 3.70$)$. A similar trend but lower than that of males and juveniles was observed in

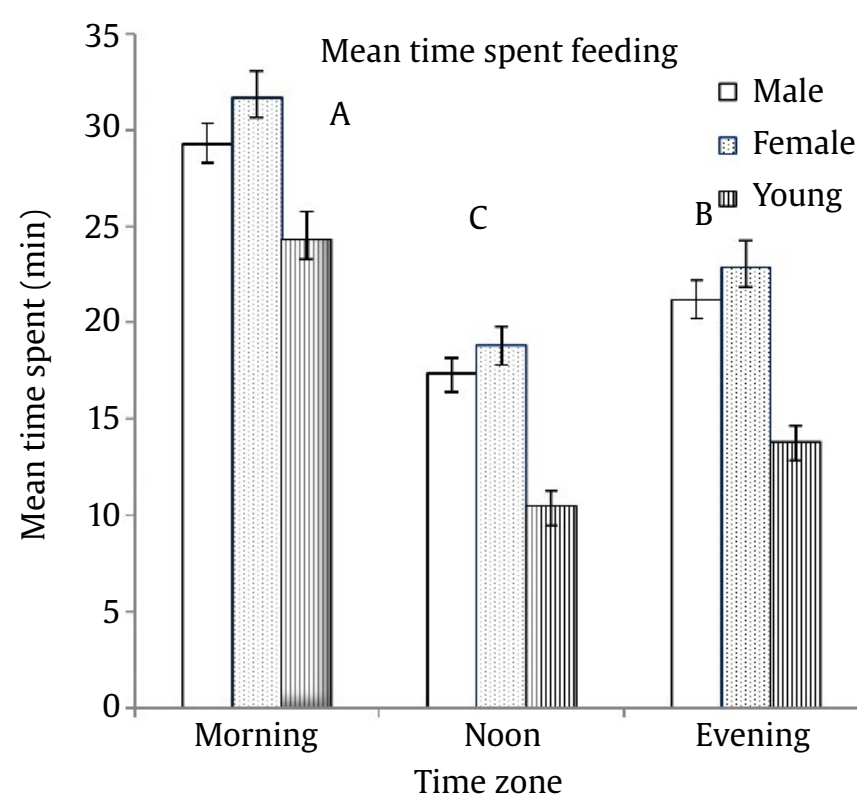

Figure 3. Mean time spent $( \pm \mathrm{SE})$ in feeding activities across the three time zones among males, females and juveniles. Feeding activity was significantly higher in the morning and evening across all three groups. Means with the same letters are not significantly different (DMRT) females (morning 4.24 \pm 2.95 , noon $2.00 \pm 1.97$, and evening 4.50 \pm 2.75$)$. Data for the time zones were significantly different $(\mathrm{F}=17.53, \mathrm{p}<0.001)$, a DMRT (Figure 5) indicated that this trend was similar in morning and evening time zones. Trends were similar in all three groups as the time and age/sex interaction was not significant $(\mathrm{F}=1.07, \mathrm{p}=0.375)$. Overall males spent more time in play behaviour $(10.98 \%)$ than females $(5.96 \%)(F=14.8903, p=$ $0.0002)$.

\subsection{Resting Behaviour}

Resting mostly occurred in the afternoon (Figure 6) $(\mathrm{F}=48.96, \mathrm{p}<0.0001)$. In males, resting was high in the afternoon (27.14 \pm 7.84$)$. Resting was lower in

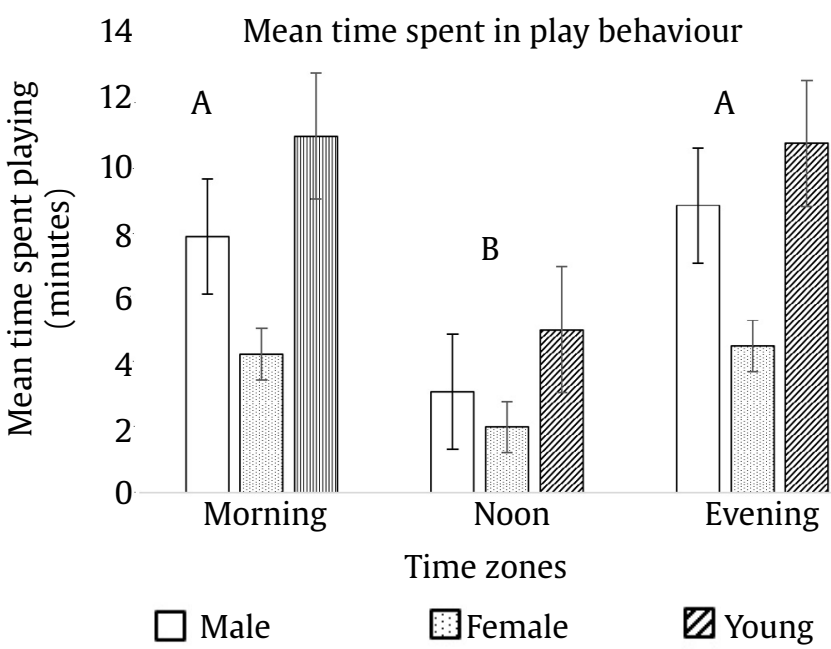

Figure 5. Mean time $( \pm$ SE) spent in play behaviour. The juveniles showed more play behaviour than adults in the morning and evening. Means with the same letters are not significantly different (DMRT)

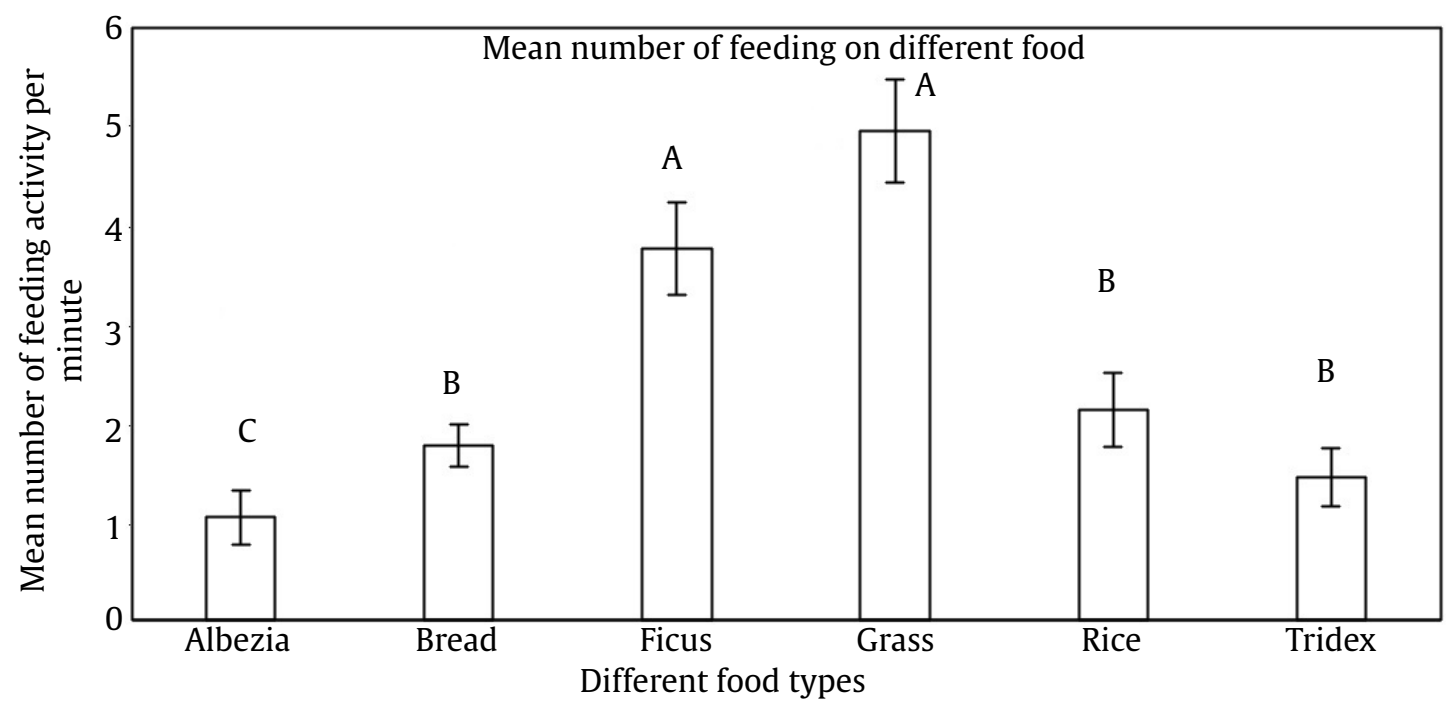

Figure 4. Mean frequency $( \pm S E)$ of feeding on different food types. Grass is the most preferred food source followed by browsing on Ficus sp. leaves. Means with the same letter are not significantly different 


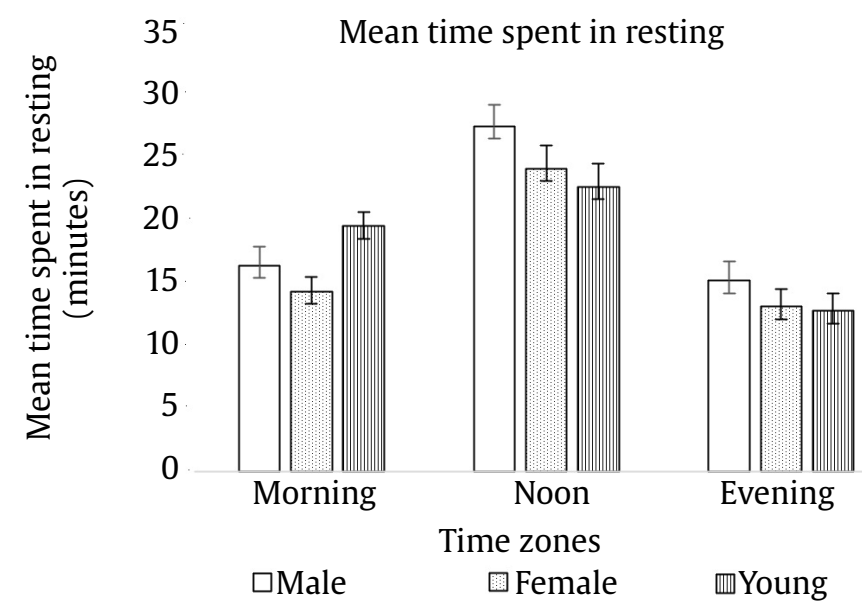

Figure 6. Mean time $( \pm \mathrm{SE})$ spent in resting. Resting was highest during the afternoon in adults and juveniles. Means with the same letters are not significantly different (DMRT)

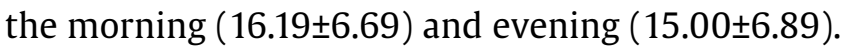
Similarly, females spent a mean time of 23.81 $( \pm 8.20)$ minutes resting in the afternoon and 14.15 $( \pm 5.19)$ and $12.96( \pm 6.30)$ minutes in the morning and evening respectively. The young spent 22.38 $( \pm 5.39)$ minutes resting in the afternoon and 19.29 $( \pm 3.96)$ and $12.62( \pm 5.84)$ minutes in the morning and evening respectively.

The mean time spent in resting between age/ sex groups were not significantly different $(F=2.79$, $\mathrm{p}=0.0643$ ). The activity trends were also similar between the males, females and juveniles as the interaction between time zones and age/sex groups was not significantly different $(F=2.74, p=0.301)$.

\section{Discussion}

This study shows that free ranging A. a. ceylonensis were active in the morning and evening, mostly feeding and playing and the afternoon was spent in resting. This is consistent with the observations made on wild Ceylon spotted deer (Eisenberg and Lockhart 1972; Phillips 1980; de Silva and de Silva 2001). But we present quantified behavioural data on the Ceylon spotted deer.

Our data provides evidence that the feeding activity may not be related to avoiding predators as the study area was devoid of predators. In the study by de Silva and de Silva (2001), the activity patterns were similar in the dry, rainy and wet seasons except for a very low numbers noted on the grass during the afternoon in the dry season. This may point to the possibility of avoidance of feeding in direct Sun. Eisenberg and Lockhart (1972) also noted that grazing continued till noon when there was cloud cover. As our study did not involve seasonal variation, it might be interesting to see whether there will be seasonal variations in feeding and resting activities in future studies.

A similar pattern of feeding in the early morning and resting in the afternoon was also noted in wild A. a. axis subspecies in North India (Tak and Lamba 1984; Dave 2008; Rajawat and Chandra 2020). The authors also discuss changes in behaviour pattern with seasons and note that there was prolonged feeding activity in the rainy season probably because of new growth in grass.

The preferred food in our study was grass (33\%) followed by browsing on Ficus sp. leaves (25\%). Eisenberg and Lockhart (1972) note that wild Ceylon spotted deer feed on the tips of an average of $1.5 \mathrm{~m}$ tall grass, fallen fruits and bark of trees. Analysis of faecal pellets of herbivorous mammals including the Ceylon spotted deer in the Udawalawe National park, Sri Lanka showed more monocot leaves than dicots (Peris et al. 2011).

The Indian subspecies of $A$. a. axis seem to show a similar preference of grazing on grass and browsing on leaves. Tak and Lamba (1984) report that the deer grazed on 15 species of grass and browse on 38 species of shrubs and trees. Browsing on Terminalia and Ficus spp. leaves were also noted in the study of Indian spotted deer (Tak and Lamba 1984). A total of 68 plant food species were noted in another study on the Indian spotted deer (Dave 2008). It is possible that the limited diversity of flora in the study area is a possible reason for the lack of variety of food consumed in our study.

Play behaviour was mostly prevalent in juveniles during morning and evening. Play was also noted in males especially during evening. Eisenberg and Lockhart (1972) wrote an anecdote that the juveniles of the Ceylon spotted deer show play behaviour during the morning visit to the waterhole.

Play behaviour of the Indian spotted deer was reported by Tak and Lamba (1984) as part of parental care, where the adults show running and other behaviour with fawns. Play behaviour observed in adults in our study may be part of parental care behaviour. It is also interesting that the play behaviour shown by males was higher than that of females. Sharatchandra and Gadgil (1980) also discuss that play behaviour is mostly shown by fawns and spike males. Graf and Nichols (1966) also note that spike males show sparring as play behaviour and not as an aggressive behaviour. Play in juvenile cervids seem to have a function of developing motor skills rather than practice for antipredator behaviour later in life (Carter et al. 2019). It may be possible that as the free 
ranging deer in our study are habituated to humans and are under less stress and hence show more play behaviour than in the wild. Graf and Nichols (1966) note that the fawns tend to show more play behaviour when 'well fed and secure from danger'.

Our study shows that there is a reduction in feeding and other activities around $1 \mathrm{pm}$. Observations on wild Ceylon spotted deer have a similar trend: 12:0014:00 hours (de Silva and de Silva 2001); 13:00 to 14:00 hours (Eisenberg and Lockhart 1972). A similar bimodal pattern of activity has been noted in the Indian spotted deer (Graf and Nichols 1966; Tak and Lamba 1984; Dave 2008; Centore et al. 2018; Rajawat and Chandra 2020).

The activity cycles of animals are influenced by light and dark cycles, predation risks, food availability etc., (Daan and Aschoff 1982). Our study shows that activities are not uniform throughout the day, most individuals were lying down and resting or ruminating but not actively feeding during noon. There is vast literature on this topic in a variety of mammals, especially of the temperate climate. An analysis of literature pertaining to the bimodal feeding activity of tropical deer seems to indicate an influence of changing seasons on the bimodal patter of activity, probably due to new growth in grass and forbs (Beier and McCullough 1990). There seems to be no indication of bimodal activity in captive conditions where food was provided in $A$. $a$. axis (Khanpara and Kauresh 2011) (Table 1) and in $C$. japonicus (Moon et al. 2000; Jeon and Moon 2002). Absence of opportunity for grazing may be related to the lack of bimodal activity. In a study of Javan deer reintroduced to Panaitan island which has very little grassland, bimodal feeding activity was less pronounced specially in males and fawns (Pairah et al. 2014). It has been postulated that crepuscular feeding/activity in ungulates is a way of avoiding

Table 1. A review of bimodal activity in species of tropical Cervinae sub family analysing the causal factors: predators/ humans, food availability, and temperature

\begin{tabular}{|c|c|c|c|c|c|c|c|}
\hline \multirow[t]{2}{*}{ Species } & \multirow[t]{2}{*}{ Predators } & \multirow[t]{2}{*}{ Temperature $\left({ }^{\circ} \mathrm{C}\right)$} & \multirow[t]{2}{*}{ Habitat } & \multicolumn{3}{|c|}{ Activity } & \multirow[t]{2}{*}{ Reference } \\
\hline & & & & $\begin{array}{r}\text { Dawn } \\
\text { peak }\end{array}$ & $\begin{array}{r}\text { Noon } \\
\text { low }\end{array}$ & $\begin{array}{r}\text { Dawn } \\
\text { peak }\end{array}$ & \\
\hline A. a. ceylonensis & $\begin{array}{l}\text { Leopard } \\
\text { Crocodile }\end{array}$ & 30 & $\begin{array}{l}\text { Wilpattu National } \\
\text { Park, Sri Lanka }\end{array}$ & 6 & 13-14 & 18 & $\begin{array}{l}\text { Eisenberg and } \\
\text { Lock-hart } \\
1972\end{array}$ \\
\hline A. a. ceylonensis & Leopard & 30 & $\begin{array}{l}\text { Yala protected } \\
\text { area, Sri Lanka }\end{array}$ & 6 & 13 & $18-20$ & $\begin{array}{l}\text { de Silva and } \\
\text { de Silva, } \\
2001\end{array}$ \\
\hline A. a. axis & Tiger, jackal & $6-44$ & $\begin{array}{l}\text { Corbett National } \\
\text { park, India }\end{array}$ & $6-7$ & $12-14$ & $18-19$ & $\begin{array}{l}\text { Tak and } \\
\text { Lamba } 1984\end{array}$ \\
\hline A. a. axis & Lion, leopard & $9-14$ & $\begin{array}{l}\text { Gir National Park, } \\
\text { Gujarat, India }\end{array}$ & $6-8$ & $12-14$ & $16-20$ & Dave 2008 \\
\hline A. a. axis & Tiger & $6-43$ & $\begin{array}{l}\text { Mukandra Hills } \\
\text { Tiger reserve, } \\
\text { India }\end{array}$ & morning & 12 & evening & $\begin{array}{l}\text { Rajawat and } \\
\text { Chandra } \\
2020\end{array}$ \\
\hline A. a. axis & & Temperate & Rab, Croatia & $6-7$ & 12 & $17-23$ & $\begin{array}{l}\text { Centore et al. } \\
2018\end{array}$ \\
\hline A. a. axis & no natural predators & $29-31$ & Hawaii & $6-8$ & 12 & evening & $\begin{array}{l}\text { Graf and } \\
\text { Nicholas } \\
1966\end{array}$ \\
\hline A. a. axis & Human visitors & $10-38$ & $\begin{array}{l}\text { Captive in Gujarat } \\
\text { zoo }\end{array}$ & & & & $\begin{array}{l}\text { Khanpara and } \\
\text { Kauresh } \\
2011\end{array}$ \\
\hline Cervus nippon & & temperate & $\begin{array}{l}\text { Captive, fed ad } \\
\text { libitum on hay }\end{array}$ & & & & $\begin{array}{l}\text { Moon et al. } \\
2000\end{array}$ \\
\hline C. nippon & & temperate & $\begin{array}{l}\text { Farmed, fed } \\
\text { on hay and } \\
\text { concentrates }\end{array}$ & & & & $\begin{array}{l}\text { Jeon and } \\
\text { Moon } 2002\end{array}$ \\
\hline C. eldi & No predators & Tropical & $\begin{array}{l}\text { Hainan Nature } \\
\text { reserve, China }\end{array}$ & & & & $\begin{array}{l}\text { Ding et al. } \\
2012\end{array}$ \\
\hline Rusa timorensis & Crocodile & 24-32 tropical & $\begin{array}{l}\text { Banteh, Indonesia } \\
\text { small grazing } \\
\text { area }\end{array}$ & & & & $\begin{array}{l}\text { Pairah et al. } \\
2014\end{array}$ \\
\hline
\end{tabular}


predators (Leuthold 1977). Our study and a study done on C. eldi in China (Ding et al. 2012) seem to indicate that bimodal activity pattern is observed even in the absence of predators. A possible alternate factor is a thermoregulatory function (Pagon et al. 2013). It is possible that as deer prefer grazing, they seek shades of trees at noon to avoid being directly under the hot Sun at noon. A study on primate species in the dry zone of Sri Lanka reports resting in the afternoon and feeding during the morning and late evening (Riyas Ahamed and Dharmaretnam 2003). In another study on primates in the Central Province of Sri Lanka, reports a correlation between ambient temperature and movement, indicating a thermoregulatory function (Weerasekara and Ranawana 2018).

In conclusion, it could be said that our study provides quantified behavioural data on a population of free ranging Ceylon spotted deer. The subjects showed a bimodal activity pattern: mainly active about an hour after dawn and dusk compared to the afternoon when resting was more common. The main activities recorded were feeding and play behaviour, the latter displayed mainly by juveniles. Grass was the preferred food followed by Ficus sp. for browsing. Any conservation plans should include grassland for feeding and suitable trees and shrubs for browsing and resting. The $A$. a. ceylonensis population in the Trincomalee is unique as they are habituated to human presence and devoid of predation pressure. Findings from our study can aid conservation plans as there will be more awareness of preferred feed, areas for resting and play behaviour. There is a dearth of grass area and water bodies in the study area at present.

\section{Acknowledgements}

I wish to extend my special thanks to M.J. Haris for the map of Trincomalee and A.B.M. Munazir for the photograph of Spotted deer.

\section{References}

Altman., 1974. Observational study of behaviour: sampling methods. Behaviour. 49, 227-266. https://doi. org/10.1163/156853974X00534

Balasubramaniam, S., Santiapillai, C., Chambers, M.R., 1980. Seasonal shifts in the pattern of habitat utilization by the spotted deer (Axis axis Erxleben 1777) in the Ruhuna National Park, Sri Lanka. Spixiana. 3, 157-166.

Beier, P., McCullough, D., 1990. Factors Influencing whitetailed deer activity patterns and habitat use. Wildlife Monographs 109:3-51.

Burghardt, G.M., 2005. Play in fishes, frogs and reptiles. Current. Biology. 25, 9-10. https://doi.org/10.1016/j. cub.2014.10.027
Carter, R.N., Romanow, C.A., Pellis, S.M, Lingle, S., 2019. Play for prey: do deer fawns play to develop speciestypical antipredator tactics or to prepare for the unexpected?. Animal Behaviour. 156, 31-40. https:// doi.org/10.1016/j.anbehav.2019.06.032

Centore, L., Ugarković, D., Scaravelli, D., Safner, T., Pandurić, K., Śprem, N., 2018 Locomotor activity patterns of two recently introduced non-native ungulate species in a Mediterranean habitat. Folia. Zool.67, 17-24. ttps:// doi.org/10.25225/fozo.v67.i1.a1.2018

Daan, S., Aschoff, J., 1982. Circadian Contributions to Survival. In: Aschoff J, Daan S, Groos GA (Eds.). Vertebrate Circadian Systems. Proceedings in Life Sciences. Springer: Berlin, Heidelberg. https://doi. org/10.1007/978-3-642-68651-1_34

Daily news., 2018. March 27th. Available at: https://www. dailynews.lk/comment/reply/146671 [Date accessed: 6 December 2020]

Dave, C.V., 2008. Ecology of Chital (Axis axis) in Gir [Thesis] India: Saurashtra University.

de Silva, M., de Silva, P.K., 2001. Group composition, sex ratio and seasonality of spotted deer (Axis axis) in the Yala Protected Area Complex, Sri Lanka. Journal of South Asian natural history. 5, 135-141.

Eisenberg, J.F., Lockhart, M., 1972. An ecological reconnaissance of Wilpattu National Park, Ceylon. Smithsonian Contributions to Zoology. 101, 37-47. https://doi.org/10.5479/si.00810282.101

Ellerman, J., Morrison-Scott, T., 1951. Checklist of Palaearctic and Indian mammals, 1758 to 1946. British Museum: London. https://ia902701.us.archive.org/24/items/ checklistofpalae00elle/checklistofpalae00elle.pdf

English, A.W., 1992. Management Strategies for Farmed Chital Deer. In: Brown RD (Eds.). The Biology of Deer. Springer: New York. https://doi.org/10.1007/978-14612-2782-3 46

Graf, W., Nichols, Jr., 1966. The axis deer in Hawaii. Journal of the Bombay Natural History Society. 63, 629-734.

Jeon, B.T., Moon, S.H., 2002. Study on the rumination behaviour of spotted deer Cervus nippon equipped with EMG telemetry system. J. of Korean. grassl sci. 22, 161-168. https://doi.org/10.5333/KGFS.2002.22.3.161

Ding, J., Liu, Z., Song, Y., Zeng, Z., Zhang, Q., Bravery. B.D. 2012. Rut-induced changes in the activity budgets of male tropical ungulates: Eld's deer on Hainan Island. Current Zoology. 58, 536-540. https://doi.org/10.1093/ czoolo/58.4.536

Khadka, G., 2012. A Case Study of Management Practices of Spotted Deer (Axis axis) in Godawari Research Centre and Central Zoo. Available at: http://www.academia. edu/3889705/Management_Practices_Of_Spotted_ Deer_In_Godawari_Deer_Research_Center_GDRC and_Central_Zoo_Nepal?auto=download [Date Accessed: 2 January 2021]

Khanpara, P.S., Kauresh, D.V., 2011. Time budget and activity pattern of behavioural displays of captive Axis deer (Axis axis). Perspectives in animal ecology and reproduction. 3, 233-250.

Leuthold, W., 1977. African ungulates: a comparative review of their ethology and behavioral ecology. Zoophysiology. Ecol. 8, 1-307.

Lever, C., 1985. Naturalized Animals of the World. Longman, London.

Moe, S.R., Wegge, P., 1994. Spacing behaviour and habitat use of Axis deer (Axis axis) in lowland Nepal. Canadian journal of zoology. 72, 1735-1744. https:/| doi.org/10.1139/z94-234

Moon, S.H., Jeon, B.T., Lee, S.M., Kim, K.H., Hudson, R.J. 2000 . Seasonal comparison of voluntary intake and feeding behavior in Korean spotted deer. Asian-Aus. J. Anim. Sci. 13, 1394-1398. https://doi.org/10.5713/ ajas.2000.1394 
Pagon, N., Grignolio, S., Pipia, A., Bongi, P., Bertolucci, C., Apollonio, M., 2013. Seasonal variation of activity patterns in roe deer in a temperate forested area. Chronobiol. Int. 30, 772-785. https://doi.org/10.3109 /07420528.2013.765887

Pairah., Santosa, Y., Prasetyo, L.B., Mustari, A.B., 2014. The time budget of Javan deer (Rusa timorensis, Blainville 1822 ) in Panaitan Island, Ujung Kulon National Park, Banten, Indonesia. HAYATI. J. Biosci. 21, 121-126. https://doi.org/10.4308/hjb.21.3.121

Peris, U.K.L., Padmalal, U.K.G.K., Bamunuarachchi, A., 2011. Habitat Use Py Large Mammalian Herbivores in Udawalawe National Park, Sri Lanka. OUSL Academic Sessions, Colombo.

Phillips, W.W.A., 1980. Manual of Mammals of Sri Lanka. 2nd edition. Wildlife and Nature Protection Society of Sri Lanka, Colombo.

Prater, S.H., 1971. The Book of Indian Animals. Bombay Natural History Society, Bombay.

Rajawat, R.S., Chandra, S., 2020. Activity pattern of Chital (Axis axis) in Mukandra Hills Tiger Reserve, India. International Journal of Ecology and Environmental Studies, 46, 173-176.

Riyas, A., Dharmaretnam, M., 2003. Home range, ranging pattern, feeding and time budget of langurs (Semnopithecus entellus) in a recently established home range. JSc-EUSL. 3, 1-10.
Santiapillai, C., Wijeyamohan, S., 2003. The impact of civil war on wildlife in Sri Lanka. Current. science. 84, 11821183.

Sharatchandra, H.C., Gadgil, M., 1980 On the time-budget of different life-history stages of chital (Axis axis).J. Bombay. Nat. Hist. Soc. 75, 949-960.

Sutherland, W.J., 1998. The importance of behavioral studies in conservation biology. Animal. Behaviour. 56, 801809. https://doi.org/10.1006/anbe.1998.0896

Tak, P.C., Lamba, B.S., 1984. Ecology and Ethology of the Spotted Deer, Axis axis axis (Erexleben). Kolkata: Records of the Zoological Survey of India, Occasional Paper No. 43. pp. 100.

Vas, J., Andersen, I.L., 2015. Density-dependent spacing behaviour and activity budget in pregnant, domestic goats (Capra hircus). PLoS ONE. 10, e0144583. https:// doi.org/10.1371/journal.pone.0144583

Weerakoon, D.K., 2012. The Taxonomy and Conservation Status of Mammals in Sri Lanka. In: Weerakoon DK, Wijesundara S (Eds.). The National Red List 2012 of Sri Lanka; Conservation Status of the Fauna and Flora. Colombo: Ministry of Environment. pp. 134-144.

Weerasekara, W.M.L.S., Ranawana, K.B., 2018. Effect of temperature on activity budgets of free ranging Dusky Toque Macaques (Macaca sinica aurifrons): a case study from Peradeniya University premises, Sri Lanka. Ceylon Journal of Science. 47, 69-75. https:// doi.org/10.4038/cjs.v47i1.7489 